\title{
Timelapse of an isolated sea-breeze thunderstorm
}

\section{Cesar Azorin-Molina}

Pyrenean Institute of Ecology, Zaragoza, Spain

Low-level convergence due to sea breezes under offshore large-scale synoptic flow in the eastern regions of the Iberian Peninsula sometimes leads to the development of a sea-breeze front that triggers convection which may occasionally be extraordinarily severe, causing significant rainfall, hail and gusty winds. Sea-breeze thunderstorm cells can develop unexpectedly under weakly defined synoptic-scale or mesoscale precursor disturbances and therefore may be missed by the operational forecasts.

A sharply defined discontinuity and seabreeze convergence intensification on 4 July 2011 is shown in Figure 1 in a sequence of 35 images at five-minute intervals taken from Sierra Perenchiza (Chiva), near Valencia (Spain), looking northnorthwest towards the Iberian mountains. This timelapse reveals the formation and evolution of a significant sea-breeze thunderstorm from cumulus (Cu) through its mature stage to its dissipation. The short-lived seabreeze front consisted of two cumulonimbus clouds $(\mathrm{Cb})$ and precipitating cells. From 1030 to 1050 uTC, Cu fractus, Cu humilis, Cu mediocris and $\mathrm{Cu}$ congestus clouds grew as warm, moist and potentially unstable air transported by valley- and sea-breezes continued to rise, and the primary $\mathrm{Cb}$ cloud cell appeared from 1055 UTC. After about 70 minutes (1205 UTC), this cell began to dissipate and, as a consequence of the horizontal convergence at the outflow from it, a secondary $\mathrm{Cb}$ storm developed abruptly from 1210, lasting until 1255 UTC. The peak activity of the sea-breeze thunderstorm thus lasted for about two hours, with the last few frames showing the dissipating stage when the downdraughts in the convective clouds dominated over the updraughts and the storm died away,

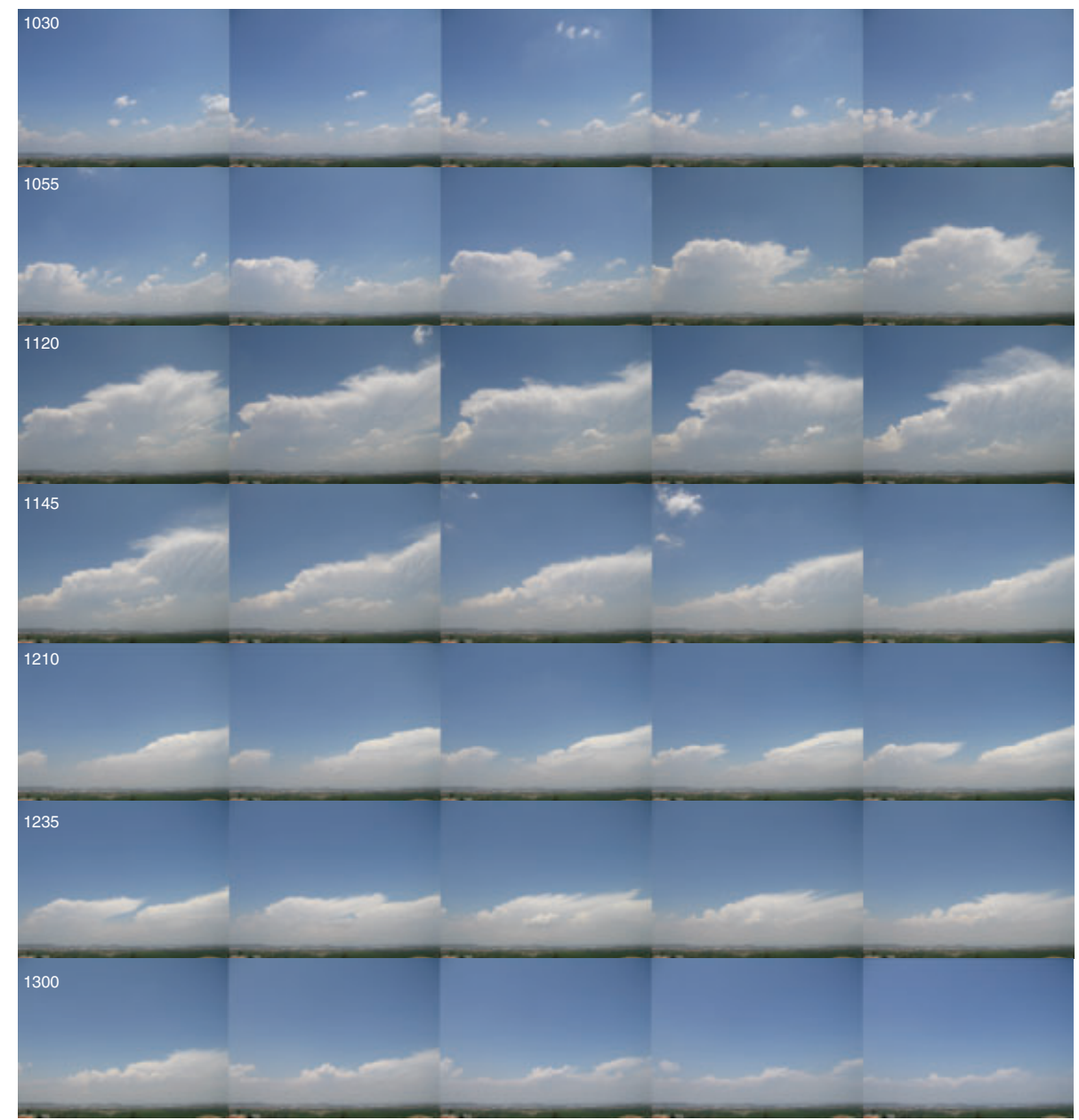

Figure 1. Development and decay of a thunderstorm set off by a sea breeze over the eastern Mediterranean mountains of the Iberian Peninsula between 1030 and 1320 UTC on 4 July 2011. Times of first frame in each row are shown, and each successive frame is five minutes later.

leaving light rain. The isolated thunderstorm moved slowly towards the Mediterranean Sea, extending a distinctive anvil eastwards due to the prevailing westerly flow aloft as a weak upper trough receded eastwards.

The timelapse is an ideal photographic technique for studying time-variable atmospheric processes such as the deep convection associated with sea breezes.
Correspondence to: Cesar Azorin-Molina, Department of Geo-environmental Processes and Global Change, Pyrenean Institute of Ecology - CSIC (Spanish Research Council). Avda. Montañana 1005, 50059 Zaragoza, Spain cazorin@ipe.csic.es

(c) Royal Meteorological Society, 2012

DOI: 10.1002/wea.1916 